\title{
Genotoxicity Screening of Industrial Effluents using Onion bulbs (Allium cepa L.)
}

\section{${ }^{1}$ *OLORUNFEMI, D I; ${ }^{1}$ OGIESERI, U M; ${ }^{2}$ AKINBORO, A}

\author{
${ }^{I}$ Department of Plant Biology and Biotechnology, University of Benin, Benin City, Nigeria \\ ${ }^{2}$ Department of Pure and Applied Biology, Ladoke Akintola University of Technology, Ogbomosho, Nigeria \\ *Correspondence author: E-mail: udanfem@gmail.com \\ Tel: $+234-802-337-2455$
}

\begin{abstract}
The potential cytotoxicity and genotoxicity of three industrial wastewaters (brewery, rubber and bottling) in Benin metropolis using the Allium cepa test were investigated. A series of five small onion bulbs were cultivated in $0.01,0.1,1$, and $10 \%$ of the wastewaters (v/v) and after 48 hours, one root tip from each bulb was harvested and processed for cytological studies by the aceto-orcein squash technique. At $72 \mathrm{~h}$, their cytotoxic effects on the root tips showed strong growth retardation in high concentrations of all the wastewaters. Compared to the control, treatment with the wastewaters resulted in root growth inhibition with $\mathrm{EC}_{50}$ values of 35,50 and $62 \%$ for bottling, rubber and brewery effluents respectively, and decrease in mitotic index with increasing concentration for all samples and these were statistically significant $(\mathrm{p}<0.05)$. Chromosomal aberrations induced in the onion root tip cells were mostly sticky chromosomes and bridges. Chromosomes with disturbed spindles and fragments were also present in appreciable amounts. Based on the $\mathrm{EC}_{50}$ values, the bottling wastewater was most toxic, followed by rubber effluent while effluents from the brewery were least toxic. The findings in this study indicate that there are toxic chemicals present in the wastewaters which are responsible for the observed genotoxic effects on the onion root tip cells. The study also reveals that the Allium test is a useful and reliable tool for the genotoxicity screening of industrial effluents which could be employed by environmental managers before these effluents are finally discharged into the environment. @JASEM
\end{abstract}

Industries are undoubtedly indispensable components of a nation's development; however, the impact of industrial wastewaters on aquatic and terrestrial ecosystems has drawn a lot of attention worldwide because of its overwhelming environmental significance. Industrial wastewater originates from the wet nature of most large industries which require large quantities of water for processing and disposal of wastes. Most industries are therefore, located near water sources. Industrial wastewater is not only concentrated but plentiful, so the pollution potential of industrial wastewater is by far greater than that of domestic wastewater. In Nigeria, over $80 \%$ of the industries discharge solid wastes, liquid effluents and gaseous emissions directly into the environment without any treatment (Federal Ministry of Water Resources, 1994). Despite existing legislations, of the 200 randomly assessed industries, only $18 \%$ perform rudimentary recycling prior to disposal of the wastes (FEPA, 1998).

Several higher plant systems, including bioassays with plant roots have provided cheaper, easier, sensitive, useful, reliable and valuable alternative methods for the determination of the adverse effects of environmental pollutants to the usual assays carried out on experimental animals (Grant, 1978). Most of the studies indicate that there is an excellent correlation between chromosome abnormalities and mutagenic activity found in root-tip systems and those found in mammalian cell systems. Observation of the root tip system of plants therefore constitutes a rapid and sensitive method for environmental monitoring (Majer et al., 2005). Allium cepa L. has been used as a first-tier assay for the detection of environmental chemicals that may pose genetic hazards from a wide range of pollutants such as sewage effluents (Ukaegbu and Odeigah, 2009), leacheates (Bakare and Wale-Adeyemo, 2004, Chandra et al., 2005) and chemicals (Seetharaman et $a l ., 2004)$. Cytotoxicity and environmental pollution have been assessed by the in vivo onion (Allium серa) root tip cell test which is known to give similar results to in vitro animal cytotoxicity tests (Vicentini et al., 2001; Teixeira et al., 2003). A. cepa test has also been used by many authors to evaluate cytotoxicity and genotoxicity of industrial effluents (Rank and Nielson, 1998; Chauhan et al., 1999; Grover and Kaur, 1999; El-Shahaby et al., 2003, Babatunde and Bakare, 2006; Junior et al., 2007; Abdel-Migid et al., 2007; Şık et al., 2009; Samuel et al., 2010).

In a study conducted on the toxicity of wastewaters from three industrial establishments in Benin City, Nigeria, differential lethality was established on Chironomus travalensis (Diptera larvae) (Olomukoro and Okhumale, 2008). We are not aware of any reports on the genotoxicity of these industrial effluents. This study was therefore undertaken to corroborate or otherwise, the nature and extent of toxicity of the effluents discharged from the same industrial establishments using a higher plant monitoring system, the Allium cepa assay.

\section{MATERIALS AND METHODS}

Three industrial effluents: a brewery $(\mathrm{Br})$, bottling company $(\mathrm{Bt})$ and rubber processing industry ( $\mathrm{Rr}$ ) were collected from their discharged points within the Benin City metropolis situated between latitudes $6^{\circ} 06^{\prime} \mathrm{N}, 6^{\circ} 30^{\prime} \mathrm{N}$ and longitudes $5^{\circ} 30^{\prime} \mathrm{E}, 5^{\circ} 45^{\prime} \mathrm{E}$ and an area of about 500 square kilometres. Effluents from these industries are discharged into close-by rivers; the brewery $(\mathrm{Br})$ and rubber processing industry $(\mathrm{Rr})$ effluents are discharged into the Ikpoba 
river while the effluent from the bottling company (Bt) are discharged into the Iguosa river.

Onion bulbs (Allium cepa $\mathrm{L}$., $2 \mathrm{n}=16$ ) of the purple variety of average size (15-22 mm diameter) were purchased locally in Benin City, Edo State, Nigeria. They were sun-dried for six weeks and the dried roots present at the base of the onion bulbs were carefully shaved off with a sharp razor blade to expose the fresh meristematic tissues. The bulbs were then placed in freshly prepared distilled water to protect the primordial cells from drying up. To account for a number of bulbs in the population that would be naturally slow or poor growing, seven replicate bulbs were used for each test sample and control (tap water) and the best five bulbs were chosen for examination (Rank and Nielsen, 1993). The bulbs were removed from the distilled water and placed on a blotting paper to remove excess water. For root growth inhibition evaluation, the bulbs were exposed directly in $0,1,5,10,25,50,75$ and $100 \%$ (v/v, effluent/tap water) of each of the test samples. Seven onion bulbs were utilized for each concentration of each wastewater and the control. The base of each of the bulbs was suspended on the effluents inside $100 \mathrm{ml}$ beakers in the dark for $72 \mathrm{~h}$. Test effluents were changed daily. At the end of the exposure period, the roots of five onion bulbs with the best growth at each concentration were removed with a forceps and their lengths measured (in $\mathrm{cm}$ ) with a metre rule. The effect of each sample on the morphology of growing roots was also examined. For the evaluation of induction of chromosomal aberration, five onion bulbs were suspended on 10 , $1,0.1$, and $0.01 \%$ concentrations $(\mathrm{v} / \mathrm{v})$ of each of the effluents and the control for $48 \mathrm{~h}$, at the end of which root tips from these bulbs were cut and fixed in ethanol:glacial acetic acid $(3: 1, \mathrm{v} / \mathrm{v})$. These were hydrolyzed in $1 \mathrm{~N} \mathrm{HCl}$ at $60^{\circ} \mathrm{C}$ for five minutes after which they were washed in distilled water. Two root tips were then squashed on each slide, stained with aceto-carmine for $10 \mathrm{~min}$ and cover slips carefully lowered on it to exclude air bubbles. The cover slips were sealed on the slides with clear fingernail polish as suggested by Grant (1982). This is to prevent drying out of the preparation by the heat of the microscope (Sharma, 1983). Six slides were prepared for each concentration and the control out of which five were analyzed at $\times 1000$ magnification for induction of chromosomal aberrations. The mitotic index was calculated as the number of dividing cells per 1000 observed cells (Fiskesjo, 1985, 1997). The frequency of aberrant cells (\%) was calculated based on the number of aberrant cells per total cells scored at each concentration of each effluent (Bakare et al., 2000).

The effluents were analyzed for a number of standard physico-chemical properties, including dissolved oxygen (DO), total dissolved solids (TDS), biochemical oxygen demand $\left(\mathrm{BOD}_{5}\right)$, chlorides, nitrates, and phosphates, according to methods described by APHA (1998). Nine metals (including seven heavy metals) namely: lead, cadmium, copper, iron, zinc, nickel, and manganese were analyzed in the effluent samples according to standard analytical methods (USEPA, 1996; APHA, 1998). Briefly, 100 $\mathrm{ml}$ of the effluents were digested by heating with concentrated $\mathrm{HNO}_{3}$, and the volume reduced to 3-5 $\mathrm{ml}$. This volume was made up to $10 \mathrm{ml}$ with $0.1 \mathrm{~N}$ $\mathrm{HNO}_{3}$. Concentrations of the metals were estimated by using an Atomic Absorption Spectrophotometer (Perkin Eelmer E. Analyst, 2000, USA).

The means, with $95 \%$ confidence limits and the standard errors for results of the root inhibition and chromosome aberrations at each concentration of the wastewaters were calculated. Data were expressed as Mean \pm Standard Error of Mean (SEM). Differences between the control and different concentrations of the wastewaters were analyzed using the Student's unpaired $t$-test. Values of $\mathrm{p} \leq 0.05$ were considered to be statistically significant. All statistical analyses were carried out using SPSS®14.0 statistical package.

\section{RESULTS AND DISCUSSION}

The physical and chemical properties of the different wastewaters from a bottling plant $(\mathrm{Bt})$, a rubber processing industry $(\mathrm{Rr})$ and a brewery $(\mathrm{Br})$ at their discharge points are presented in Table 1 . The effluents were characterized by considerable pollutants of suspended matter, dissolved matters and high values of turbidity. The $\mathrm{pH}$ of effluents of the bottling plant $(\mathrm{Bt})$ was alkaline (10.50) while those of the rubber processing plant $(\mathrm{Rr})$ and brewery $(\mathrm{Br})$ were acidic $(4.75$ and 5.50 respectively. The effluents were characterized by high mean values of total hardness: 417, 320, and 298 for $\mathrm{Bt}, \mathrm{Rr}$, and $\mathrm{Br}$ respectively. Mean values of total suspended solids (TSS) were 34, 40, and 48 for $\mathrm{Bt}, \mathrm{Rr}$, and $\mathrm{Br}$ respectively and these were all above limits set for discharge into surface water. Similarly, total hardness of the effluents $(417,320$ and 298) for $\mathrm{Bt}, \mathrm{Rr}$, and $\mathrm{Br}$ respectively, and turbidity exceeded the maximum permissible limits required by WHO. The BOD value in the effluent of $\mathrm{Bt}$ (19.90) was highest followed by $\mathrm{Br}(15.10)$ and was least in $\mathrm{Rr}$ (12). Lead, manganese, cadmium, copper, iron, zinc, and nickel were detected in all the wastewater samples. The overall average levels of most of the parameters of all the three industrial effluents at their discharge points were much higher than the discharge standards set by regulatory bodies (FEPA 1991, USEPA 1999, WHO 1996). These values were out of range with stipulated standards, indicating lack of wastewater treatment prior to discharge. The low DO values from the effluents compared to 
FMENV (1992) standards suggest that these industries were producing a lot of organic substances which are high oxygen-demanding wastes (Emongor et al 2005). The relatively high levels of alkalinity could be attributed to low levels of DO. The discharge of phosphate salts and detergents used for washing in the factory is a regular source of phosphate in the wastewaters at the discharge point, and since the levels of total hardness were higher than the $100-150 \mathrm{mg} / \mathrm{l}$ values normally classified as slightly hard (Onianwa et al., 1999), the effluents could contribute significantly to the hardness of the rivers.

Table 1: Mean values of water quality parameters of industrial effluents in Benin City at discharge point.

\begin{tabular}{|c|c|c|c|c|c|c|}
\hline Parameter & Bt & $\mathbf{R r}$ & $\mathrm{Br}$ & FEPA $^{\text {a }}$ & USEPA $^{b}$ & WHO $^{\mathrm{c}}$ \\
\hline Temperature $\left({ }^{\circ} \mathrm{C}\right)$ & 30 & 31 & 28 & $<40$ & NS & NS \\
\hline $\mathrm{pH}$ & 10.5 & 4.75 & 5.5 & $6-9$ & $6.5-8.5$ & $6.5-9.5$ \\
\hline Turbidity (FTU) & 68 & 98 & 38 & NS & NS & 5 \\
\hline Total Hardness & 417 & 320 & 298 & NS & $0-75$ & 500 \\
\hline TSS & 43 & 40 & 48 & 30 & NS & NS \\
\hline TDS & 430 & 720 & 1500 & 2000 & 500 & $<1200$ \\
\hline $\mathrm{BOD}_{5} @ 20^{\circ} \mathrm{C}$ & 19.90 & 12 & 15.10 & 50 & NS & NS \\
\hline DO & 2.13 & 4.24 & 2.72 & NS & NS & NS \\
\hline Alkalinity & 750 & 340 & 230 & NS & NS & NS \\
\hline Total solids & 715 & 1012 & 1970 & NS & NS & NS \\
\hline Nitrates & 50.00 & 86.50 & 54 & 20 & 10 & 50 \\
\hline Sulphates & 78.00 & 67.50 & 18 & 500 & 250 & 500 \\
\hline Phosphates & 0.91 & 1.15 & 0.28 & 5 & NS & NS \\
\hline Chlorides & 248.50 & 276.90 & 335 & 600 & 250 & 250 \\
\hline Calcium & 306 & 220 & 250 & 200 & NS & NS \\
\hline Copper & 0.02 & 0.1 & 0.32 & $<1$ & 0.009 & NS \\
\hline Manganese & 0.1 & 0.1 & 0.1 & 5 & 0.05 & NS \\
\hline Lead & 0.1 & 0.1 & 0.1 & $<1$ & 0.003 & 0.01 \\
\hline Iron & 0.64 & 0.24 & 0.40 & 20 & 0.30 & NS \\
\hline Cadmium & 0.07 & 0.01 & 0.03 & $<1$ & 0.002 & 0.003 \\
\hline Nickel & 0.12 & 0.1 & 0.15 & $<1$ & 0.005 & 0.02 \\
\hline Zinc & 0.06 & 0.3 & 2.03 & $<1$ & 0.12 & 0.01 \\
\hline
\end{tabular}

Values are means of 3 replicates \pm SEM; *All values are in $\mathrm{mg} / \mathrm{L}$ except temperature, turbidity, and pH with no unit; BOD: Biochemical oxygen demand; DO: Dissolved oxygen; TDS: Total dissolved solids; TSS: Total suspended solids; NS: Not stated; ${ }^{a}$ Federal Environmental Protection Agency (1991) Permissible limits for effluent discharge into surface water; ${ }^{b}$ United States Environmental Protection Agency (1999).National recommended water quality criteria - correction; ${ }^{c}$ World Health Organisation (1996). Guideline for drinking water quality recommendation

The mean root lengths of $A$. cepa grown in the industrial effluents are shown in Table 2. Generally, root growth retardation was observed in all the tested effluents; high growth rate was recorded in onion bulbs exposed to low concentrations and vice versa. In particular, mean root lengths obtained from onion bulbs grown in the wastewaters were in the decreasing order: $\mathrm{Bt}>\mathrm{Rr}>\mathrm{Br}$ at all concentrations, for instance, \% root growth of control for the stock sample of $\mathrm{Bt}$ was 28.9 while those of $\mathrm{Rr}$ and $\mathrm{Br}$ were 46.98 and 53.63 respectively. Compared to the onion bulbs grown in the control, the root tips of onion bulbs grown in the industrial effluents were characterized by twists and crotchet roots (roots bent upwards resembling hooks). The induction of root malformations in A. cepa has been shown to be useful signs of toxicity in previous studies (Babatunde and Bakare, 2006, Bakare et al., 2009, Olorunfemi et al., 2011). Results from cytotoxic and genotoxic evaluation of the industrial effluents are indicative of a linear relationship between macroscopic and microscopic parameters for all the wastewaters. There was concentration-dependent decrease in root growth and the order of induction of root growth inhibition based on $\mathrm{EC}_{50}$ values was $\mathrm{Bt}>\mathrm{Rr}>\mathrm{Br}$ effluents. These values indicate that the samples were toxic; comparatively, the Bt effluent has the most inhibitory and mitodepressive effects than all the other effluents.

Table 2: Root length of Allium cepa after cultivation in different concentrations of industrial effluents.

\begin{tabular}{|c|c|c|c|c|c|c|c|c|c|}
\hline \multirow{2}{*}{$\begin{array}{l}\text { Conc } \\
(\%)\end{array}$} & \multicolumn{3}{|c|}{ Bt } & \multicolumn{3}{|c|}{$\mathbf{R r}$} & \multicolumn{3}{|c|}{$\mathrm{Br}$} \\
\hline & $\begin{array}{c}\text { Mean Root } \\
\text { length } \pm \text { S.E. }(\mathrm{cm})\end{array}$ & $\begin{array}{c}\mathrm{RG}(\%) \text { of } \\
\text { control }\end{array}$ & $\begin{array}{c}95 \% \\
\text { CL }\end{array}$ & $\begin{array}{c}\text { Mean Root } \\
\text { length } \pm \text { S.E. }(\mathrm{cm})\end{array}$ & $\begin{array}{c}\mathrm{RG}(\%) \text { of } \\
\text { control }\end{array}$ & $\begin{array}{c}95 \% \\
\text { CL }\end{array}$ & $\begin{array}{c}\text { Mean Root } \\
\text { length } \pm \text { S.E. }(\mathrm{cm})\end{array}$ & $\begin{array}{c}\mathrm{RG}(\%) \text { of } \\
\text { control }\end{array}$ & $\begin{array}{c}95 \% \\
\text { CL }\end{array}$ \\
\hline 0 & $3.60 \pm 0.20$ & 100 & 44 & $3.60 \pm 0.20$ & 100 & 44 & $3.60 \pm 0.20$ & 100 & 44 \\
\hline 1 & $2.97 \pm 0.17$ & 82.20 & 38 & $3.18 \pm 0.18$ & 88.41 & 38 & $3.37 \pm 0.18$ & 93.61 & 38 \\
\hline 5 & $2.91 \pm 0.28$ & 80.80 & 63 & $2.99 \pm 0.26$ & 83.06 & 41 & $3.15 \pm 0.22$ & 87.52 & 40 \\
\hline 10 & $2.48 \pm 0.27$ & 68.90 & 66 & $2.86 \pm 0.31$ & 79.44 & 62 & $3.14 \pm 0.17$ & 87.22 & 24 \\
\hline
\end{tabular}




\begin{tabular}{|c|c|c|c|c|c|c|c|c|c|}
\hline 25 & $2.01 \pm 0.18$ & 55.80 & 39 & $2.69 \pm 0.21$ & 74.72 & 53 & $3.13 \pm 0.15$ & 86.90 & 33 \\
\hline 50 & $1.87 \pm 0.13$ & 51.90 & 29 & $2.58 \pm 0.22$ & 71.67 & 41 & $3.02 \pm 0.10$ & 84.55 & 26 \\
\hline 75 & $1.76 \pm 0.12$ & 48.90 & 31 & $2.35 \pm 0.14$ & 65.28 & 41 & $2.87 \pm 0.09$ & 79.71 & 18 \\
\hline 100 & $1.04 \pm 0.08$ & 28.90 & 41 & $1.69 \pm 0.09$ & 46.98 & 41 & $2.07 \pm 0.10$ & 53.63 & 20 \\
\hline $\mathrm{EC}_{50}$ & & $35 \%$ & & & $50 \%$ & & & $62 \%$ & \\
\hline
\end{tabular}

RG (\%) of control expressed as \% root growth of the control; 95\%CL: $95 \%$ confidence limit. $* P \leq 0.05$, level of significance of root growth inhibition compared with the untreated control. p values, (>0.05) level as compared to controls, Values are Mean \pm SEM

Results of the microscopic analysis of the treated Allium cepa root tips are summarised in Tables 3 and 4. Chromosomal aberrations were induced at all the tested concentrations and were statistically significant $(\mathrm{p}<0.05)$. The most frequent aberrations were bridges and sticky chromosomes; of these $\mathrm{Bt}$ effluent had the highest number, followed by effluents from Rr. Chromosomes with disturbed spindles and fragments were also present in appreciable amounts. In $A$. серa, whenever chromosome aberrations occurred, there were almost always certain growth restrictions. Sticky chromosomes represent poisoned chromosomes with sticky surface and probably lead to cell death
(Fiskesjo, 1997). Sticky chromosomes at metaphase and anaphase stages were abundant in the Allium test indicating that these effluents contain substances that are very toxic. The results of physico-chemical analyses corroborate this assertion. The fact that $\mathrm{Bt}$ effluent had the highest number of sticky chromosomes suggests that it is the most toxic of the effluents. Conversely, $\mathrm{Br}$ with the least number of these aberrant chromosomes suggests that it is the least toxic. Also frequent were bridges and fragments; such anomalies (i.e. the induction of chromosomal fragments and bridges at anaphase) give an indication of mutagenic events in the cell (Mishra, 1993).

Table 3: Cytological effects of effluents of $\mathrm{Bt}, \mathrm{Rr}$ and $\mathrm{Br}$ on cells of Allium cepa $\mathrm{L}$.

\begin{tabular}{|c|c|c|c|c|c|c|c|c|c|}
\hline \multirow[b]{2}{*}{ Conc $(\%)$} & \multicolumn{3}{|c|}{ Bt } & \multicolumn{3}{|c|}{$\mathbf{R r}$} & \multicolumn{3}{|c|}{ Br } \\
\hline & $\begin{array}{c}\text { No. of } \\
\text { dividing cells }\end{array}$ & $\begin{array}{c}\text { Mitotic } \\
\text { index }\end{array}$ & $\begin{array}{c}\% \text { of } \\
\text { aberrant } \\
\text { cells }\end{array}$ & $\begin{array}{l}\text { No. of } \\
\text { dividing } \\
\text { cells }\end{array}$ & $\begin{array}{c}\text { Mitotic } \\
\text { index }\end{array}$ & $\begin{array}{c}\% \text { of } \\
\text { aberrant } \\
\text { cells }\end{array}$ & $\begin{array}{l}\text { No. of } \\
\text { dividing } \\
\text { cells. }\end{array}$ & $\begin{array}{c}\text { Mitotic } \\
\text { index }\end{array}$ & $\begin{array}{c}\% \text { of } \\
\text { aberrant cells }\end{array}$ \\
\hline 0 & 660 & 13.20 & - & 660 & 13.20 & - & 660 & 13.20 & - \\
\hline 0.01 & 430 & 8.60 & 4.88 & 480 & 9.60 & 2.29 & 490 & 9.80 & 2.45 \\
\hline 0.1 & 370 & 7.40 & 5.14 & 388 & 7.76 & 4.38 & 410 & 8.20 & 3.66 \\
\hline 1 & 311 & 6.22 & 7.08 & 306 & 6.12 & 7.51 & 397 & 7.94 & 3.78 \\
\hline 10 & 298 & 5.96 & 7.72 & 300 & 6.00 & 7.33 & 314 & 6.28 & 5.41 \\
\hline
\end{tabular}

$* 5000$ cells per conc. of each effluent and the control

Compared to the control value of 13.20 , there were lower mitotic indexes with increasing concentrations in all the effluents. In particular, the lowest MI value of 5.96 was recorded for $10 \% \mathrm{Bt}$ effluent, while MI values of 6.00 and 6.28 were recorded for $\mathrm{Rr}$ and $\mathrm{Br}$ effluents at the same concentration respectively. Conversely, there was increase in mitotic inhibition values with increasing concentration in all effluents (Table 4). The decline of mitotic index and increase in mitotic inhibition in $A$. серa with increasing concentrations of wastewaters reflects cytotoxicity.
Compared to the control, mitotic index values recorded at various effluent concentrations showed decline in the order $\mathrm{Bt}>\mathrm{Rr}>\mathrm{Br}$ while the mitotic inhibition values were in the increasing order $\mathrm{Bt}<\mathrm{Rr}<\mathrm{Br}$. These results are in agreement with our earlier studies (Olorunfemi and Ewhre, 2010, Olorunfemi et al., 2011) and studies of other workers (Samuel et al., 2010). Decline of mitotic index below $22 \%$ in comparison to negative control can cause lethal effects on the organism (Antonsiewicz, 1990).

\begin{tabular}{|c|c|c|c|c|c|c|c|c|c|c|c|c|}
\hline \multirow{2}{*}{ 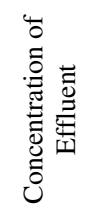 } & \multicolumn{9}{|c|}{ Chromosome aberration per 1000 cells } & \multirow{2}{*}{ 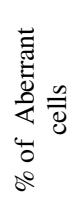 } & \multirow[b]{2}{*}{ : } & \multirow{2}{*}{ 总总 } \\
\hline & $\frac{\frac{0}{\tilde{U}}}{\frac{0}{0}}$ & 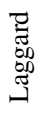 & 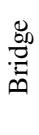 & 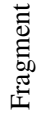 & 苛 & 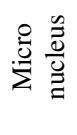 & 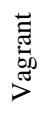 & . & 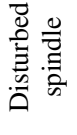 & & & \\
\hline $\begin{array}{l}\text { Control } \\
B t\end{array}$ & - & - & - & - & - & - & - & - & - & - & 13.20 & - \\
\hline $0.01 \%$ & 3 & 2 & 4 & 2 & 6 & 1 & 1 & 1 & 1 & 4.88 & 8.60 & 34.9 \\
\hline $0.1 \%$ & 2 & 1 & 4 & 3 & 5 & - & 1 & 2 & 1 & 5.14 & 7.40 & 43.9 \\
\hline $1 \%$ & 1 & 3 & 4 & 3 & 6 & 1 & 2 & 1 & - & 7.08 & 6.22 & 52.9 \\
\hline $10 \%$ & 1 & 1 & 6 & 3 & 7 & 1 & 2 & 1 & 1 & 7.72 & 5.96 & 54.9 \\
\hline
\end{tabular}

OLORUNFEMI, D I; OGIESERI, U M; AKINBORO, A 


\begin{tabular}{|c|c|c|c|c|c|c|c|c|c|c|c|c|}
\hline \multicolumn{13}{|l|}{$R r$} \\
\hline $0.01 \%$ & 1 & 2 & 3 & 1 & 1 & 1 & - & - & 2 & 2.29 & 9.60 & 27.3 \\
\hline $0.1 \%$ & - & 4 & 4 & 1 & 1 & 1 & - & - & 6 & 4.38 & 7.76 & 41.2 \\
\hline $1 \%$ & - & 4 & 3 & 4 & 2 & 5 & 1 & - & 3 & 7.51 & 6.12 & 53.6 \\
\hline $10 \%$ & 1 & 3 & 5 & 2 & 7 & 1 & - & - & 3 & 7.33 & 6.00 & 54.6 \\
\hline \multicolumn{13}{|l|}{$B r$} \\
\hline 0.01 & 1 & 3 & 4 & 1 & 1 & 1 & - & - & 1 & 2.45 & 9.80 & 25.8 \\
\hline $0.1 \%$ & 1 & 4 & 2 & 2 & 4 & 1 & - & - & 1 & 3.66 & 8.20 & 37.9 \\
\hline $1 \%$ & 3 & 1 & 5 & 1 & 4 & - & - & - & 1 & 3.78 & 7.94 & 39.9 \\
\hline $10 \%$ & 2 & 4 & 3 & 2 & 2 & - & - & - & 4 & 5.41 & 6.28 & 52.4 \\
\hline
\end{tabular}

Results from this study shows that a strong correlation exist between the cytological values obtained with the differential toxic response of Chironomus travalensis kieffer to the industrial effluents earlier investigated (Olomukoro and Okhumale, 2008). In a study on the cytogenotoxicity evaluation of two industrial effluents using Allium cepa assay (Samuel et al., 2010), the authors suggested that the onion root growth test should be fully integrated into the Whole Effluent Toxicity (WET) programme by giving a particular $\mathrm{EC}_{50}$ that an industrial effluent must meet before being allowed to be discharged into the aquatic environment. Results of this study have also shown that A. cepa chromosomal assay is a reliable tool for monitoring the genotoxic effects of industrial effluents and wastewaters; it would undoubtedly serve as a useful tool for monitoring the genotoxic effects of industrial effluents and wastewaters before they are discharged into the environment.

\section{REFERENCES}

Abdel-Migid, HM; Azab, YA; Ibrahim, WM (2007). Use of plant genotoxicity bioassay for the evaluation of efficiency of algal biofilters in bioremediation of toxic industrial effluent, Ecotoxicology and Environmental Safety. 66: 57-64.

American Public Health Association, APHA (1998). Standard Methods for the Examination of Water and Wastewater. 20th ed. American Public Health Association, Washington DC, $1220 \mathrm{pp}$.

Antonise-Wiez, D (1990). Analysis of the cell cycle in root meristem of Allium cepa under the influence of Ledakrin. Folia Histochemical Cytobiologia 26: 79-96.

Babatunde, BB; Bakare, AA (2006). Genotoxicity screening of wastewaters from Agbara Industrial Estate, Nigeria evaluated with the Allium test. Pollution Research 25(2): 227-234

Bakare, AA; Mosuro, AA; Osibanjo, O (2000). Effect of simulated leachate on chromosomes and mitosis in roots of Allium cepa (L). Journal of Environmental Biology 21(3): 263 - 271.

Bakare, AA; Wale-Adeyemo, AR (2004). The mutagenic and cytotoxic effects of leacheates from domestic solid wastes and Aba-Eku landfill, Nigeria on Allium cepa. Nature, Environment and Pollution Technology 3: 455462.

OLORUNFEMI, D I; OGIESERI, U M; AKINBORO, A
Bakare, AA; Okunola, AA; Adetunji, OA; Jenmi, HB (2009) Genotoxicity assessment of a pharmaceutical effluent using four bioassays Genetics and Molecular Biology 32(2): 373-381

Chandra, S; Cauhan, LKS; Murthy, RC; Saxena, PN; Pande, PN; Gupta, SK (2005). Comparative biomonitoring of leachates from hazardous solid waste of two industries using Allium test. Science of the Total Environment 347:46-52.

Chauhan LKS; Saxena, PN; Gupta, SK (1999). Cytogenetic effects of cypermethrin and fenvalerate on the root meristem cells of Allium cepa. Environmental and Experimental Botany 42: 181 - 189.

El-Shahaby, OA; Abdel-Migid, HM; Soliman, MI; Mashaly, IA (2003). Genotoxicity screening of industrial wastewater using the Allium cepa chromosome aberration assay. Pakistan Journal of Biological Sciences 6: 23-28.

Emongor, V; Kealotswe, E; Koorapetse, I; Sankwansa, S; Keikanetswe, S (2005). Pollution indicators in Gaberone effluent. Journal of Applied Science 5: 147150

Federal Environmental Protection Agency (FEPA) (1991). S1.8 National Environmental Protection (Effluent Limitations) regulations 1991 as cited by Odiete (1991). In: Environmental Physiology of Animals and Pollution, Published by Diversified Resources Ltd., Lagos, Nigeria. pp. 157-219.

Federal Environmental Protection Agency (FEPA) (1998). Industrial Pollution Policy Management Study. FEPA

Federal Ministry of Water Resources (1994). The study of the National Water Resources masterplan under Japan International Cooperation Agency (JICA), Abuja. Federal Ministry of Water Resources.

Fiskesjö, G. (1985) Allium test on river water from Braan and Sexan before and after closure of a chemical factory. Ambiologia, 14: 99-103.

Fiskesjö, G (1997). Allium test for screening chemicals: Evaluation of cytologic parameters. In: Plants for Environmental Studies, Wang, W., Gorsuch, J.W., Hughes, J.S. (eds), CRC Lewis Publishers, Boca Raton, New York. pp. 308-333.

FMENV (1992). National Environmental Protection Agency (Effluent Limitations) Regulations 1991. 
Grant, WF (1978). Chromosome aberrations in plants as a monitoring system. Environmental Health Perspectives, 27:37-43.

Grant, WF (1982). Chromosome aberration assays in Allium. A report of the United States Environmental Protection Agency Gene Toxicity Program. Mutation Research, 99: 273-291.

Grover IS; Kaur, S (1999). Genotoxicity of wastewater samples from sewage and industrial effluent detected by the Allium root anaphase aberration and micronucleus assays. Mutation Research. 426: $183-$ 188.

Junior, HM; da-Silva, J; Arenzon, A; Portela, CS; de-SaFerreira, IC; Henriques, JAP (2007). Evaluation of genotoxicity and toxicity of water and sediment samples from a Brazilian stream influenced by tannery industries. Chemosphere 67: 1211 - 1217.

Majer, BJ; Grummt, T; Uhi, M, Knasmuller, S (2005). Use of plant assays for the detection of genotoxins in the aquatic environment. Acta of Hydrochemistry and Hydrobiology 33: 45-55

Mishra, K. (1993). Cytotoxic effects of distillery waste on Allium cepa L. Bulletin Environmental Toxicology, 50: 199-204

Olomukoro, JO; Okhumale, BO (2008). Differential toxic response of Chironomus travalensis kieffer

(Chironomidae: Diptera) to some industrial effluents. Toxicological and Environmental Chemistry 90(6): 1197-1202

Olorunfemi, DI; Okoloko, GE; Bakare, AA; Akinboro, A (2011). Cytotoxic and genotoxic effects of cassava effluents using the Allium cepa test, Research Journal of Mutagenesis 1: 1-9

Olorunfemi, DI; Ehwre, EO (2010). Chromosomal aberrations induced in root tips of Allium cepa by squeezed garri extracts Report and Opinion 2(12) 166171

Onianwa, PC; Ogunniyi, OJ; Ogunlowo, AA (1999). General physicochemical quality of drinking water in Ibadan, Nigeria, International. Journal of Environmental Education Information 18(2): 143-154

Rank, J; Nielsen, MH. (1993). A modified Allium test as a tool in the screening of the genotoxicity of complex mixtures. Hereditas 118: 49-53.
Rank, J; Nielsen, MH (1998). Genotoxicity testing of wastewater sludge using the Allium cepa anaphasetelophase chromosome aberration assays. Mutation Research 418: 113 - 119.

Samuel, OB; Osuala, F; Odeigah, PGC (2010). Cytogenotoxicity evaluation of two industrial effluents using Allium cepa assay. African Journal of Environmental Science and Technology 4(1): 21-27

Seetharaman, N; Dhanavel, D; Vembu, B (2004). Effects of induced heavy metal, nickel on somatic chromosomes of Allium cepa. Nature, Environment and Pollution Technology 3: 481-484.

Sharma, CBSR (1983) Plant meristems as monitors of genetic toxicity of environmental chemicals. Current Science. 52: 1000-1002.

Şık, L, Acar, O; Aki, C (2009). Genotoxic effects of industrial wastewater on Allium cepa L. African Journal of Biotechnology 8(9): 1919-1923.

Teixeira RO, Comparoto ML, Mantovani MS, Vicentini VEP (2003). Assessment of two medicinal plants Psidium guajava L. and Achillea millefolium L., in vitro and in vivo assays. Genetics and Molecular Biology 26: 551-555.

Ukaegbu, MC; Odeigah, GC (2009). The genotoxic effect sewage effluent on Allium cepa. Report and Opinion 1(6): $36-41$

United States Environmental Protection Agency (USEPA). (1996) Acid digestion of sediments, sludges and soil method - 3050B. USEPA, Washington, DC.

United States Environmental Protection Agency (USEPA) (1999). National recommended water quality criteria Correction: EPA 822/Z-99-001, USEPA, Washington DC.

Vicentini, VEP; Camparoto, ML; Teixeira, RO; Mantovani, MS (2001). Averrhoa carambola L., Syzygium cumini (L) Skeels and Cissus sicoydes L.: Medicinal herbal tea effects on vegetal and animal test systems. Acta Scientiarum 23: 593 - 598.

World Health Organisation (WHO) (1996). Guideline for Drinking Water Quality Recommendations 2, World Health Organisation, Geneva 